\title{
A incorporação das normativas mercosulinas e as constituições dos estados-partes: o desafio das superações da normatividade estatal*
}

Maria Elizabeth Guimarães Teixeira Rocha ${ }^{11}$

\section{Resumo}

O presente artigo analisará o processo de incorporação das normativas mercosulinas emanadas pelos órgãos decisórios do bloco, com vistas a avaliar os progressos do processo integracionista na área jurídica. Para tanto, serão contempladas, separadamente, as Constituições de cada Estado-Parte a fim de se aferir a importância atribuída ao Direito do Mercosul nas ordens jurídicas nacionais.

Palavras-chave: Mercosul. Direito da Integração. Normativas mercosulinas. Intergovernabilidade. Constituição.

\section{Introdução}

A internacionalização do Direito Regional do Mercado Comum do Sul perpassa necessariamente pela adoção e eficácia das normas originárias e derivadas do bloco pelos Estados Partes que o compõem, bem como pelas cláusulas de integração de suas Constituições, mais ou menos permeáveis às determinações legais exógenas. Conceber um conjunto de normas comunitárias sem efetividade, não apenas revela-se inútil, como descortina a incipiência do processo integracionista. Alicerce jurídico-institucional, a transposição das regras emanadas pelos órgãos decisórios do Mercosul para as ordens positivas nacionais é imperiosa para o al-

\footnotetext{
* Recebido em 31.01.2001.

Aprovado em 25.02.2001.

1 Mestra em Ciências Jurídico-Políticas pela Universidade Católica de Lisboa. Doutora em Direito Constitucional pela Universidade Federal de Minas Gerais. Ministra do Superior Tribunal Militar. Professora da Faculdade de Direito do UniCEUB e líder do Grupo de Pesquisa de Estudos sobre o Mercosul.
} 
cance das obrigações e a coerência sistêmica do bloco. As análises a seguir empreendidas contemplarão o processo de elaboração das normas no âmbito do Mercosul e a regulação constitucional específicas dos Estados-Partes, com vistas a aferir a projeção das determinações mercosulinas nas relações compartidas da soberania.

\section{As normativas do Mercosul}

O Tratado de Assunção e o Protocolo² de Ouro Preto definiram a estrutura institucional do ator regional Mercosul, integrado por órgãos decisórios de caráter intergovernamental, por um sistema consensual de tomada de decisões e por um sistema arbitral de soluções de controvérsias.

Conforme disposto no artigo $1^{\circ}$ do Protocolo, ${ }^{*}$ a estrutura interna do Mercosul é composta pelo Conselho do Mercado Comum (CMC); o Grupo Mercado Comum (GMC); a Comissão de Comércio do Mercosul (CCM); o Foro Consultivo Econômico-Social (FCES) e a Secretaria Administrativa do Mercosul (SAM).

Os órgãos com capacidade decisória são: o Conselho do Mercado Comum -CMC, o Grupo Mercado Comum- GMC e a Comissão de Comércio do Mercosul - CCM, de natureza intergovernamental e não supranacional.

Funcionam, ainda, como órgãos auxiliares do Mercosul, cuja criação está prevista pelo art. $1^{\circ}$, parágrafo único, do Protocolo de Ouro Preto, grupos de trabalho, grupos técnicos, grupos de coordenadores, grupos ad hoc, subgrupos, reuniões de especialistas, reuniões ministeriais, comissões, fóruns, comitês técnicos,

2 "Artigo 1. A estrutura institucional do Mercosul contará com os seguintes órgãos

I. O Conselho do Mercado Comum (CMC);

II. O Grupo Mercado Comum (GMC);

III. A Comissão de Comércio do Mercosul (CCM);

IV. A Comissão Parlamentar Conjunta (CPC);

V. O Foro Consultivo Econômico-Social (FCES);

VI. A Secretaria Administrativa do Mercosul (SAM).

Parágrafo único - Poderão ser criados, nos termos do presente Protocolo, os órgãos auxiliares que se fizerem necessários à consecução dos objetivos do processo de integração." 
dentre outros, criados e convocados de forma dinâmica, sempre e quando se considere sua necessidade.

Nesse sentido, o Mercosul conta com órgãos temáticos tais como: a Comissão Sociolaboral (CSL), o Fórum de Consulta e Concertação Política (FCCP), os Grupos de Alto Nível, os Subgrupos de Trabalho (SGT) dependentes do GMC, os Comitês Técnicos (CT) dependentes do CCM, o Observatório do Mercado de Trabalho (OMT) dependente do SGT10 e o Fórum da Mulher no âmbito do FCES. Há ainda as Reuniões de Ministros (RM), Reuniões Especializadas (RE) e Reuniões ad hoc.

Dentro do propósito de fortalecimento institucional, foi criado por meio da Resolução n 54/03, de 10 de dezembro de 2003, do GMC, o Tribunal Administrativo-Trabalhista, denominado TAL, por suas iniciais em castelhano: Tribunal Administrativo-Laboral. A função do TAL é solucionar as reclamações administrativo-trabalhista dos funcionários da Secretaria do bloco, bem como tarefas ou serviços pela Secretaria ou pelos demais órgãos da estrutura institucional do Mercosul.

Para além, o Protocolo de Olivos, firmado em 18 de fevereiro de 2002, estabeleceu a criação do Tribunal Permanente de Revisão, que por ser o primeiro órgão supranacional do Mercosul impõe comentários. Segundo o estatuído no Protocolo, o Tribunal terá caráter permanente e seus integrantes deverão dedicar-se em regime de exclusividade. É composto por cinco árbitros, com seus respectivos suplentes, eleitos por cada Estado Parte por um mandato de dois anos, renovável por dois períodos consecutivos.

O quinto árbitro, com mandato de três anos não renovável, será eleito por unanimidade pelos Estados Partes - artigos 18 e 19 do Protocolo de Olivos. O funcionamento do Tribunal dá-se de forma variável. Se a controvérsia apresentada perante o Tribunal envolve dois estados do bloco, a Corte funcionará com três árbitros, sendo dois deles da nacionalidade dos países litigantes, enquanto o terceiro será de nacionalidade de um país membro que esteja fora da disputa, e a eleição será feita por sorteio realizado pelo Diretor da Secretaria Administrativa - SAM. Se a con- 
trovérsia envolver mais de dois Estados-Partes, o Tribunal funcionará com todos seus árbitros, ou seja, cinco - art. 20 do Protocolo de Olivos. Por fim, as decisões do Tribunal, denominadas laudos arbitrais, serão de caráter obrigatório para os estados litigantes desde o momento de sua notificação, tendo força de coisa julgada.

A conformação de tal órgão encontra pontos de fertilização cruzada com outros atores internacionais, que possuem estrutura semelhante ao Órgão de Solução de Controvérsias do OMC. Efetivamente, o TPR terá papel relevante no trabalho de uniformização e interpretação jurisprudencial acerca de questões controversas no interior do bloco. Sua jurisdição supranacional representa o primeiro passo em direção ao ideal comunitário.

Inicialmente, cumpre destacar a existência de um verdadeiro ordenamento legal autônomo no âmbito do Mercado Comum do Sul, caracterizado como um conjunto estruturado de normas jurídicas de nível regional que possui suas próprias fontes e encontra-se dotado de órgãos e procedimentos aptos a produzi-las. ${ }^{3}$

Mas, é possível estabelecer um escalonamento hierárquico jurídico, após a edição do Protocolo de Brasília, das normas mercosulinas, que têm no ápice da pirâmide o direito regional originário: os tratados constitutivos e seus protocolos adicionais; seguidos pelas normas regionais de direito derivado que deverão observar a lógica instituída pelo Tratado de Assunção; a saber: as decisões do CMC, as

\footnotetext{
${ }^{3}$ Naquele instrumento restaram enumeradas as fontes a serem observadas pelo tribunal arbitral ad hoc. O Protocolo de Olivos, que em seu art. 55 derroga expressamente o Protocolo de Brasília para Solução de Controvérsias, amplia a gama de normas aplicáveis ao bloco regional quando dispõe:

"Art. 34- Os Tribunais Arbitrais ad hoc e o Tribunal Permanente de Revisão decidirão a controvérsia com base no Tratado de Assunção, no Protocolo de Ouro Preto, nos protocolos e acordos celebrados no marco do Tratado de Assunção, nas decisões do Conselho do Mercado Comum, nas Resoluções do Grupo Mercado Comum e nas Diretrizes da Comissão de Comércio do Mercosul, bem como nos princípios e disposições de Direito Internacional aplicáveis à matéria."

As fontes jurídicas do Mercosul, portanto, adaptam-se ao processo de integração.

Não obstante, afirmaria PERROTI, Alejandro; "[...] excelentes vientos han comenzado a soplar en las tierras jurisdiccionales de los Estados Partes del MERCOSUR, al menos en lo que hace a la relación entre las Cortes Supremas de Justicia y el Tribunal Permanente de Revisión del bloque.
} 
resoluções do GMC e as diretrizes do CCM, conforme identificados pelo Protocolo de Ouro Preto.

Por seu turno, dentro do direito regional derivado, a hierarquia subsume-se segundo o órgão que ditou a norma. Em consequência, as decisões emanadas dos órgãos superiores do Mercosul prevalecem sobre as resoluções do órgão executivo e estas sobre as diretrizes, na medida em que a Comissão de Comércio subordina-se ao Grupo do Mercado Comum. Posto isto, infere-se que os diversos atos jurídicos dos órgãos decisórios do Mercosul possuem distinta valoração jurídica, em face de sua diferente natureza, como também da posição institucional dos órgãos dos quais elas emanam.

Fato é que o Protocolo de Ouro Preto apontou, tão somente, as fontes internas do Mercosul, no entanto, trata-se de enumeração meramente exemplificativa

En este sentido, la Acordada No 7.604 de la Suprema Corte de Justicia de la República Oriental del Uruguay, de 24/08/2007, que reglamenta internamente el procedimiento que deben seguir - en Uruguay - los jueces internos que decidan solicitar una Opinión Consultiva al Tribunal Permanente de Revisión del MERCOSUR.

Constituye la primera Corte Suprema que reglamenta el mecanismo, dando cumplimiento así a la obligación creada por el párrafo segundo del artículo 1 de la Decisión No 02/07 del Consejo del Mercado Común ("Reglamento del Procedimiento para la solicitud de Opiniones Consultivas al Tribunal Permanente de Revisión por los Tribunales Superiores de Justicia de los Estados Partes del MERCOSUR"), a cuyo tenor "Cada Tribunal Superior de Justicia de los Estados Partes, en el ámbito de sus respectivas jurisdicciones, establecerá las reglas internas de procedimiento para la solicitud de opiniones consultivas a que se refiere este Reglamento, verificando la adecuación procesal de la solicitud". Cabe recordar que según el artículo 9 del Protocolo de Ouro Preto, "El Consejo del Mercado Común se pronunciará mediante Decisiones, las que serán obligatorias para los Estados Partes".

La Decisión No 02/07 del Consejo del Mercado Común - a pesar de establecer expresamente la innecesariedad de su incorporación al derecho interno de los Estados Partes - fue transpuesta el ordenamiento uruguayo por el Decreto 209/007, de 18/06/2007.

Una consulta que queda pendiente, en relación a la presente reglamentación uruguaya, es si ella cubre también el procedimiento que deberá aplicar el Tribunal de lo Contencioso Administrativo de Uruguay, ya que la Acordada de la SJC se refiere - en su ámbito de aplicación - a "cualquier órgano del Poder Judicial". Al respecto, cabría consultarse si el Tribunal de lo Contencioso Administrativo forma parte del "Poder Judicial", interrogante que nuestros colegas uruguayos están en mejores condiciones de responder (ver, al respecto, artículos 77, inciso. 4 , 194, 220 y 258, párr. $2^{\circ}$, de la Constitución de Uruguay y 51 de la Ley 15.750, Orgánica de la Judicatura, de 24/06/1985; DO 08/07/85, No 21.973). 
porquanto os princípios gerais do direito internacional público, as normas positivas dos Estados Nacionais membros, os tratados da OMC e a própria Convenção de Viena sobre o Direito dos Tratados, que o Brasil não ratificou, mas adota como norma costumeira, são, igualmente, fontes externas do Mercosul. Concernente a tais fontes, cumpre salientar que o Mercosul, ao contrário do ator regional, União Europeia, não dispõe de princípios gerais de direito regional comunitário, nem de jurisprudência comunitária, por não se ter conferido ao bloco prerrogativas supranacionais.

\subsection{Da incorporação e aplicação das normativas Mercosul}

A dificuldade que se impõe sobre a aplicabilidade das normas comunitárias não respeita ao Direito regional originário, vez que os instrumentos constitutivos devem acatar os procedimentos jurídicos estatuídos pelas Constituições nacionais em matéria de tratados, respeita, sim, à aplicação do direito regional derivado, por suscitar questões de ordem constitucional entre os integrantes dos Estados Membros vez que evoca a compatibilidade das Leis Magnas com a organização internacional, tendo como maior desafio estruturar um sistema de órgãos que imponha, de forma cogente aos Estados Nacionais integrantes, as normativas regionais comunitárias, bem como estabeleça mecanismos para sua aplicabilidade direta e eficácia imediata, erga omnes, na esfera nacional.

Sobre a matéria, estatuiu o capítulo IV do Protocolo de Ouro Preto que "[...] as normas emanadas dos órgãos do Mercosul [...] terão caráter obrigatório e deverão, quando necessário, ser incorporadas aos ordenamentos de cada país.” A expressão quando necessário deixa bem claro que a incorporação não se aplica a todos os casos, e mais, da inteligência do artigo deflui que cada país poderá internalizá-las em conformidade com seus ordenamentos legais. Ademais, o Protocolo dispõe de um procedimento de policronia relativamente moroso para a entrada em vigor da legislação secundária que, sinteticamente, pode ser assim descrito:

a) uma vez aprovada a norma regional, os Estados Nacionais adotarão as medidas necessárias para sua incorporação ao ordenamento 
jurídico nacional e comunicarão à Secretaria Administrativa do Mercosul quando estiverem internalizadas;

b) quando todos os Estados houverem informado a incorporação, a Secretaria Administrativa do Mercosul comunicará o fato a cada Estado Nacional membro, e por fim; e

c) as normas entrarão em vigor simultaneamente nos Estados Membros 30 dias depois da data de comunicação efetuada pela SAM. Dentro deste prazo, os Estados Nacionais darão publicidade ao início da vigência das referidas normas regionais por intermédio de seus respectivos Diários Oficiais. A aplicabilidade será simultânea nos quatro países do bloco.

À evidência, tal forma de incorporação das normativas mercosulinas constitui um verdadeiro atentado à viabilidade futura do bloco regional, já que a ausência de supranacionalidade não pode implicar na submissão de todas as decisões, resoluções e diretrizes à expressa internalização de cada Estado Nacional. " "Os Estados são, portanto, guardiões de seus próprios compromissos. A eficácia das normas comunitárias depende de diligência dos Estados Membros em adotar medidas que permitam sua aplicação" (VENTURA, 2003, p. 139).

Em tese, o direito regional derivado é obrigatório por força determinante do Tratado de Assunção e seus Protocolos complementares, como também em atendimento ao art. 18 da Convenção de Viena sobre Direito dos Tratados. A incorporação só caberia "quando fosse necessária", ou seja, quando estivesse submetida a condições constitucionais e legais para tanto, do contrário, haveria de prevalecer a chamada doutrina do "self executing" ou da autoexecutividade das normas provenientes de órgãos tanto supranacionais, quanto intergovernamentais; contudo o Protocolo de Ouro Preto afastou a possibilidade de aplicação imediata ao especificar o iter procedimental a seguir observado pelos Estados e ao estatuir a "vigência simultânea" nos ordenamentos nacionais, ex vi o caput, do art. 40 do POP.

\footnotetext{
4 Sobre esse ponto, faz-se presente o fenômeno da fertilização cruzada. Ocorre que, ao passo que no âmbito do Mercosul não se encontra a autoaplicabilidade das normas dentro de cada Estado Nacional membro, na UE as normas são autoaplicáveis para as relações entre Estados Nacionais, mas não encontram tal eficácia imediata nas relações entre indivíduos, exigindo para aplicação a internalização da norma regional.
} 
A entrada em vigor das normas do Mercosul observa, portanto, um complexo procedimento, a saber; o Estado realiza a transposição, nos moldes do art. 42 do Protocolo, observando os regramentos previstos por seus sistemas legais. Atente-se que, na atualidade, nenhum dos Estados Partes do Mercosul possui um procedimento específico de incorporação das normativas comunitárias. Os quatro parceiros adotam as determinações aplicáveis aos tratados internacionais em geral (VENTURA, 2003, p. 141).

Incorporado ao ordenamento interno, o Estado informará à Secretaria do Mercosul e esperará a comunicação daquele órgão sobre a internalização da norma pelos demais países. Somente após o recebimento da mencionada comunicação, os parceiros deverão diligenciar internamente para que a normativa comunitária entre em vigor no prazo de 30 dias. À evidência, tal procedimento confere um verdadeiro poder de veto aos Estados-Partes, poder que se apresenta de maneiras variadas e nas várias fases do processo legislativo do Mercosul.

Inicialmente, a mera ausência ou abstenção de um membro nas reuniões deliberativas permite bloquear ou retardar o processo decisório, podendo causar a crise da "cadeira vazia". Depois, caso o Estado-membro não comunique à Secretaria do Mercosul (SAM) a incorporação da normativa, sua entrada em vigor praticamente inviabiliza-se. Decorre daí, que um Estado pode impedir ou manipular datas de vigência das normas do bloco, simplesmente adiando a informação à Secretaria. Por tal razão, na prática, as normas mercosulinas produzem seus efeitos em cada país após a promulgação interna. Nenhum país espera a comunicação da SAM para aplicá-la, porque se estaria diante de mais um obstáculo à sua vigência.

Ademais, conforme observa Deisy Ventura, o Protocolo de Ouro Preto “[...] dá a entender que o direito originário do Mercosul reconhece a existência de duas ordens jurídicas paralelas, e assim admite claramente o dualismo." Nesse sentido, “[...] cabe interrogar se essa idéia de dualismo é de fato compatível com os objetivos dos tratados do Mercosul. Além disso, o procedimento de transposição das normas do Mercosul criado em Ouro Preto suscita várias dificuldades relativas à aplicação do direito derivado, principalmente no que tange à uniformidade de interpretação" (VENTURA, 2003, p. 142-143). 
Decorre daí a necessidade de instituição de mecanismos implementadores para a internalização das normas secundárias mercosulinas, questão fulcral para o processo de internacionalização. Efetivamente, a complexidade do procedimento de elaboração e transposição das normativas para as ordens jurídicas internas - posto ter o Protocolo de Ouro Preto atribuído aos governos nacionais, individualmente atingidos, a função de controle da aplicação do direito derivado do Mercosul nos limites de suas respectivas jurisdições - condicionou a eficácia das normas comunitárias à diligência dos Estados Membros em adotar medidas que permitam sua aplicação. ${ }^{5}$

Conforme se salientou, nem o Protocolo de Ouro Preto, nem as Constituições dos países integrantes do bloco, admitem a possibilidade de aplicação direta ou eficácia imediata do direito do Mercosul nas suas ordens jurídicas internas. A dificuldade que se impõe, consoante já salientado, não diz respeito ao Direito originário, mas secundário, e evoca a compatibilidade das Leis Magnas com a organização internacional, cujo maior desafio é estruturar um sistema jurídico que propicie "[...] o jogo de hierarquias alternativas e permita a expansão do processo de geração do direito que crie um enredamento de normas entre sistemas não hierarquizados" (DELMAS-MARTY, 2004, p. 103).

5 Concernente às estatuições mercosulinas, cuja transposição prescinde da interveniência do Poder Legislativo, poderiam ser elas internalizadas tal qual se faz, no Brasil, com alguns Acordos Parciais de Complementação Econômica e seus protocolos adicionais, abrigados sob a égide do Tratado de Montevidéu que instituiu a Associação Latino-Americana de Integração (ALADI).

Criada em 12 de agosto de 1980 pelo Tratado de Montevidéu, a ALADI objetivou criar um mercado comum latino-americano, em longo prazo e de maneira gradual, mediante a concessão de preferências tarifárias e acordos regionais e de alcance parcial. A ALADI substituiu a ALALC, a antiga Associação Latino-Americana de Livre Comércio, que foi criada em 1960. São Países-Membros da ALADI: Argentina, Bolívia, Brasil, Chile, Colômbia, Cuba, Equador, México, Paraguai, Peru, Uruguai e Venezuela.

Tais acordos são promulgados pelo Presidente da República do Brasil, sem a anuência do Congresso; porquanto, são considerados meros atos implementadores do Tratado de Montevidéu. Ora, o Tratado de Assunção de 1991, que constituiu o Mercosul, estatuiu, igualmente, que durante o período de transição, poderão ser adotados acordos setoriais para viabilizar a utilização e a mobilidade dos fatores de produção, bem como alcançar escalas operativas eficientes.

Assim, não sendo adotada tal sistemática, os procedimentos de transposição têm-se revelado insatisfatórios, inviabilizando a coordenação que ordenaria as distintas ordens jurídicas. 
A expressão "quando necessário", adotada pelo Protocolo de Ouro Preto, deixa claro que a incorporação não se aplica a todos os casos e que cada país poderá internalizá-las em conformidade com seus ordenamentos legais.

Ora, a despeito do direito derivado ser obrigatório por força determinante do Tratado de Assunção e seus Protocolos complementares, como também em atendimento ao art. 18 da Convenção de Viena sobre Direito dos Tratados, inexiste regramento nacional nos quatro parceiros do bloco que preveja um procedimento específico, célere e privilegiado de incorporação das normas do Mercosul. Aplica-se o previsto para qualquer fonte de direito internacional ordinário, posição adotada pelo Judiciário brasileiro que, contaminado por um formalismo obsoleto, despreza as normas oriundas do Mercosul.

A complexidade do sistema e a ausência de previsão constitucional e legal que regule a adoção das normas comunitárias, acabam por provocar a conhecida síndrome de Janus, pois possibilitam uma transposição à la carte, vez que a não incorporação das normativas do Mercosul pelos parceiros não resulta em sanção ao Estado faltoso, que pode abster-se em total impunidade. Esclareça-se que inexiste no âmbito do Mercosul "recurso em carência" ou "ação por falta", nos moldes do sistema comunitário europeu. Ainda, a operação de transmutação da norma internacional em norma doméstica, é susceptível ao princípio lex posteriori derogat priori e lex specialis derogat generali o que ocasiona uma emulação às avessas, na linguagem conceitual de Delmas-Marty. ${ }^{6}$

\footnotetext{
${ }^{6}$ A Argentina buscando implementar mecanismos institucionais que confiram às normativas mercosulinas tratamento específico e ágil, distinto do outorgado aos demais atos internacionais, propôs ao Subgrupo de Trabalho $n^{\circ} 2$ do Mercosul, que as decisões, resoluções e diretivas oriundas dos órgãos com capacidade decisória, que não requeiram aprovação legislativa, entrem em vigor nos ordenamentos jurídicos nacionais diretamente, tal qual ocorre na Comunidade Europeia. Tal proposta tem encontrado enormes resistências por parte dos juristas brasileiros e uruguaios que não admitem a adoção do referido mecanismo sem uma reforma constitucional prévia, temerosos do tão criticado "déficit democrático" e de que o Poder Executivo acabe por se tornar legislador de jure e de facto.
} 


\section{Tratamento constitucional da integração nos estados partes e o direito do Mercosul nas ordens jurídicas nacionais}

Neste ponto, convém investigar o papel do Direito Internacional frente aos sistemas constitucionais dos Estados Partes, bem como inferir a vigência e eficácia das cláusulas de integração nas Cartas Políticas dos parceiros do bloco.

Para já, enfatize-se que numa análise perfunctória, as Leis Fundamentais do Brasil, Argentina, Uruguai e Paraguai indicam a adoção do dualismo como sistema norteador para a incorporação das normas internacionais nas ordens internas estatais.

No marco do Mercosul, a questão centra-se em saber se as Constituições dos países do bloco autorizam o reconhecimento de certa singularidade ao direito de integração, ou mais além, permitem que os Estados pertençam a um órgão capaz de constituir fonte de direito autônomo, propiciando um ajustamento de relações entre eles e a Comunidade Internacional. ${ }^{7}$

O estudo das Cartas Políticas do Brasil, da Argentina, do Uruguai, do Paraguai e, eventualmente, da Venezuela, que busca o ingresso no bloco regional, contém dispositivos que respaldam o Direito da Integração, embora em diferentes dimensões de juridicidade.$^{8}$

\subsection{A constituição brasileira}

A Constituição da República Federativa do Brasil de 1988 dispõe em seu artigo $4^{\circ}$; verbis:

7 Nessa perspectiva, Mireille Delmas-Marty (2006), sustenta a necessidade de solucionar a tensão entre a competência do Estado e da Comunidade Internacional, o que se busca realizar a partir da apresentação do ajustamento das relações, por meio dos princípios da subsidiariedade e da proporcionalidade. Isso porque, o princípio da subsidiariedade ao atuar conjuntamente com o da proporcionalidade intenciona não limitar e dividir puramente a competência, mas regulá-la.

8 Sobre o tema, consultar excelente estudo sobre as Constituições dos Estados fundadores do Mercosul de autoria de Alejandro Daniel Perotti (2004). 
Art. 4 A República Federativa do Brasil rege-se nas suas relações internacionais pelos seguintes princípios:

I - independência nacional;

II - prevalência dos direitos humanos;

III - autodeterminação dos povos;

IV - não-intervenção;

$\mathrm{V}$ - igualdade entre os Estados;

VI - defesa da paz;

VII - solução pacífica dos conflitos;

VIII - repúdio ao terrorismo e ao racismo;

IX - cooperação entre os povos para o progresso da humanidade;

$\mathrm{X}$ - concessão de asilo político.

Parágrafo único. A República Federativa do Brasil buscará a integração econômica, política, social e cultural dos povos da América Latina, visando à formação de uma comunidade latino-americana de nações.

A despeito do artigo integracionista insculpido no parágrafo único, do art. $4^{\circ}$ da Lei Maior, discute-se estar-se diante de norma nacional programática que, se por um lado, deixa em aberto a forma pela qual o Brasil irá buscar a integração com os parceiros da América Latina, por outro, não torna dispensável a atuação dos instrumentos constitucionais de transposição do acervo normativo do bloco regional.

Efetivamente, a interpretação da cláusula integracionista brasileira tem gerado discussões no campo doutrinário. Para alguns autores, está-se diante de uma prescrição constitucional aberta, que necessita de regulamentação e rejeita, portanto, a hipótese de uma possível aplicação imediata da norma internacionais. Para outros, é possível interpretação condizente com a atual realidade vigente na ordem internacional, qual seja, a de que o art. 4º, parágrafo único, da Carta Magna de 1988, autoriza a participação do Brasil em processos de integração supranacionais. ${ }^{9}$

9 Sobre a matéria, escreveu Rafael Nascimento Reis (2006): "A partir de uma interpretação gramatical da norma, não encontramos nenhum obstáculo a criação de organismos su 
A discussão doutrinária sobre essa fertilização cruzada perpassa pela questão da delegação de soberania a organismos supranacionais, para além da concretização dos princípios do efeito direito e da aplicabilidade imediata das normas integracionistas do Mercado Comum do Sul.

Para a instituição de organismos supranacionais que facilitem a fertilização cruzada no ator regional Mercosul faz-se necessário a existência de três princípios: o princípio da primazia, que é a capacidade de as normas derivadas dos tratados de integração regional prevalecerem, em caso de conflito, sobre as normas de direito nacional; o princípio do efeito imediato, ou seja, a capacidade que a norma tem de ingressar no direito doméstico de cada Estado Membro, sem necessitar de incorporação por algum meio ou forma de legislação nacional; e o princípio do efeito direto, qual seja, a qualidade que a norma regional comunitária tem de produzir direitos e obrigações tanto para os Estados integrantes do bloco e instituições regionais comunitárias, quanto para atores cívicos, tais como pessoas físicas e jurídicas (PEROTTI, 2004, p. 192-193).

É certo que a soberania clássica nos moldes concebidos por Bodin já não mais vigora na contemporaneidade, no entanto, a Carta Magna Brasileira revela uma ideia de soberania arraigada ao conceito liberal, entendimento corroborado pela jurisprudência do Supremo Tribunal Federal.

pranacionais, v.g. no Mercosul, pelo contrário, o fato de o texto constitucional mencionar a expressão "integração política” permite concluir que está autorizado a delegação de competências e atribuições estatais à órgãos supranacionais no Mercosul, sem que com isto, o Brasil esteja participando ou ratificando algum acordo inconstitucional. [...] já pudemos observar que o legislador constitucional, diante de uma interpretação histórica, não apresentou obstáculos a participação do país em processos de integração. a discussão que houve, muito embora desconhecido de muitos na época, era acerca de que no processo de integração o Brasil deveria ou poderia fazer parte, ou seja, o país poderia apenas participar de processos intergovernamentais de decisão ou avançar, seguindo o paradigma da União Europeia, rumo a supranacionalidade? não se pode afirmar com toda certeza, que o legislador constitucional de 1988 e o revisor de 1994 tenham criados objeções ao aspecto supranacional, muito embora, o resultado tenha sido negativo nas tentativas de modificação do texto constitucional. no entanto, é fato hoje que a mutação constitucional, como momento de transformação da realidade constitucional, não há de esperar por reformas ou revisões constitucionais para transformação da sociedade ou adequação da interpretação constitucional a essa mesma sociedade." 
Bastos, comentando a Lex de 1988, afirma que a noção de soberania transposta para a Carta Fundamental pátria “[...] significa que dentro do nosso território não se admitirá força outra que não a dos poderes juridicamente constituídos, não podendo qualquer agente estranho à Nação intervir nos seus negócios" (BASTOS, 1994, p. 147).

Eminentes internacionalistas veem com extrema cautela as possibilidades de autorização, de acordo com o atual texto constitucional, da inserção do Brasil em um cenário de integração supranacional. Vale mencionar a posição de Luiz Olavo Baptista sobre o tema:

Trata-se aqui, fundamentalmente, de matéria de limites: o limite que as ordens constitucionais impõem e, também, os limites políticos que a vontade nacional traça, aos quais já fizemos referência. Há obstáculos na ordem constitucional para a criação de organismos supranacionais nos moldes daqueles utilizados na União Européia, tanto para o exercício de funções normativas como das judiciais, e em parte, pelo menos, das administrativas.

A principal função dos órgãos supranacionais da UE, que é a de expedir normativas e regulamentos comunitários encontra, com certeza, forte obstáculo na ordem constitucional brasileira. Um organismo como o Conselho da UE que acumula funções legislativas com as administrativas, afrontaria a regra da separação dos poderes, que faz parte da chamada cláusula pétrea da Constituição (BAPTISTA, 1995, p. 58-59).

No mesmo sentido, Ferreira Filho (1990, p. 21) explicita que a leitura que se deve fazer do art. $4^{\circ}$, parágrafo único, é de "[um objetivo prefixado para a política internacional do Brasil”. Essa interpretação restritiva do preceito constitucional parece ter origem no fato de que no interior da Assembleia Constituinte de 1988 houve quem entendesse que o preceito integracionista deveria ser alocado nos Atos das Disposições Constitucionais Transitórias, vez que, a norma nacional consubstanciava-se em um objetivo a ser alcançado no tempo, não justificando a sua inclusão no texto constitucional permanente. Assim, parte da doutrina entende que a norma integracionista é ausente de mecanismos que lhe deem aplicação imediata, resultando em mera regra programática. 
Em contraposição a tais teses, há os que defendem a aplicação imediata do mencionado preceito constitucional por acreditarem que o dispositivo confere autorização ao Brasil para buscar a integração latino-americana em uma fertilização cruzada, inclusive, com a participação em órgãos supranacionais (BASTOS; MARTINS, 1994, p. 184).

Bastos afirma que "[...] o presente dispositivo deixa certo que o País conta com a autorização constitucional para buscar a sua integração em uma comunidade latino-americana de nações” (BASTOS, 1988, p. 414). Essa parece ser a interpretação mais adequada, vez que concretiza a constituição diante dos fatores reais atuais na ordem mundial. Inconcebível seria a interpretação restritiva da norma constitucional, tendo em vista que, à época da Constituinte, o Brasil já participava de processos de integração, v.g., ALADI. Sendo assim, não haveria porque o legislador conceber a referida norma no texto constitucional, se não fosse para permitir que o país avançasse na policronia dos processos de integração, contando com a possibilidade de ingressar em órgãos supranacionais.

Na mesma direção, Perotti ressalta que o legislador constitucional foi categórico ao exprimir o princípio da autoaplicabilidade do preceito constitucional inscrito no art. $4^{\circ}$, parágrafo único (PEROTTI, 2004, p. 194). Indo além, para Gomes Canotilho verificou-se decisiva ruptura em relação à doutrina clássica que conduz a inexistência das normas constitucionais programáticas. Existem sim, normas-fim, normas-tarefas, normas-programa que 'impõem um actividade' e 'dirigem materialmente a concretização constitucional' juridicamente vinculantes, e de valor idêntico aos restantes preceitos da Constituição. (GOMES CANOTILHO, 1991, p.189-190). ${ }^{10}$

\footnotetext{
${ }^{10}$ Segundo Gomes Canotilho (1991, p. 190-191) "Em virtude da eficácia vinculativa reconhecida às 'normas programáticas', deve-se concluir que não tem qualquer sentido a oposição estabelecida por alguma doutrina entre 'norma jurídica actual' e 'norma programática' (aktuelle Rechtsnorm-Programmsatz): todas as normas são actuais, isto é, têm uma força normativa independente do acto de transformação legislativa. Não há, pois, na constituição 'simples declarações (sejam oportunas ou inoportunas, felizes ou desafortunadas, precisas ou indeterminadas) a que não se deva dar valor normativo, e só o seu conteúdo concreto poderá determinar em cada caso o alcance específico do dito valor [...].”
} 
Analisando os processos de integração dos quais o Brasil fazia parte antes da Constituição de 1988, a norma integracionista nacional desponta como um avanço conquistado ao possibilitar a supranacionalidade do bloco econômico regional, conformando uma fertilização cruzada. Isso porque, anteriormente à ordem constitucional vigente, o Brasil já participava de organismos internacionais e blocos regionais (ALADI), sob a égide do procedimento intergovernamental. Tal norma, inédita na história constitucional, só poderia objetivar, portanto, o avanço do processo de integração, dotando-o de possível caráter supranacional, caso houvesse necessidade. Nesse sentido, a mens legis emerge como mandamento autorizativo para maior participação do Estado Nacional, preservada, porém, a liberalidade de denunciar os tratados constitutivos quando o país entender que os limites mínimos de sua soberania nacional foram atingidos.

Neste contexto, os tratados constitutivos do ator regional Mercosul gozam, no ordenamento brasileiro, de status jurídico diferenciado; por tal razão, restaria vedada sua revogação ou alteração que diminuísse a integração já alcançada, porque representaria desobediência a mandamento constitucional nacional, mesmo atribuindo-se ao parágrafo único do art. $4^{\circ}$, caráter programático. Contudo, há que se ter presente que a jurisprudência brasileira não dispensa tratamento privilegiado às normas de direito regional originário e derivado do ator regional Mercosul, conferindo idêntica equivalência à norma doméstica e à norma integracionista.

Resta, enfim, analisar o procedimento de incorporação dos tratados internacionais em geral.

Adotou, o sistema constitucional brasileiro, o dualismo moderado, conforme assentado pelo Supremo Tribunal Federal em jurisprudência dominante. Isso porque, apesar de não exigir a edição de lei para o efeito de incorporação do ato internacional ao direito nacional - visão dualista extremada - exige a adoção de um iter procedimental, que compreende a aprovação congressual e a promulgação executiva do texto convencionado.

Há, pois, recepção dos tratados internacionais por um ator nacional (como o Brasil) pelo direito nacional e não sua integração, na medida em que a aplicabi- 
lidade de uma norma estrangeira na ordem jurídica nacional resulta de um procedimento de internalização, de uma efetiva "transposição" para o plano do direito endógeno, aí incluídas as convenções, tratados ou acordos celebrados no contexto regional do ator regional Mercosul. Daí decorre que, tais atos somente operarão efeitos interna corporis se uma "ordem de execução" vier a incorporá-los no ordenamento pátrio.

O mecanismo da recepção, tal como disciplinado pela Carta Política brasileira, atesta que a norma produzida externamente não dispõe, por autoridade própria, de exequibilidade e operatividade imediata de forma que, para torná-la eficaz e aplicável, mister observar-se o processo de integração delineado nos artigos 49, I, combinado com art. 84, IV.

Efetivamente, a regra de regência acerca da recepção e integração dos tratados internacionais na ordem doméstica privilegia determinados procedimentos que, sinteticamente, podem ser assim descritos:

1- O Tratado vincula internacionalmente o Estado Nacional brasileiro quando de sua ratificação ou adesão por ato do Presidente da República ou plenipotenciário, precedido da aprovação congressual;

2- Seus efeitos produzem-se interna corporis a partir da vigência assinalada no decreto editado pelo Chefe de Estado, que deve conter a íntegra do texto convencionado internacionalmente;

3- Com a publicação do decreto o tratado internacional é incorporado ao ordenamento positivo, sem a necessidade de norma legal que lhe reproduza o conteúdo.

O Supremo Tribunal Federal em acórdão prolatado no Agravo Regimental em Carta Rogatória no 8.279-4, ponderou que:

O exame da Carta Política promulgada em 1988 permite constatar que a execução dos tratados internacionais e a sua incorporação à ordem jurídica interna [nacional] decorrem, no sistema adotado pelo Brasil, de um ato subjetivamente complexo, resultante da conjugação de duas vontades homogêneas: a do Congresso Nacional, que 
resolve definitivamente, mediante decreto legislativo, sobre tratados, acordos ou atos internacionais (CF, art. 49, I), e a do Presidente da República, que, além de poder celebrar esses atos de direito internacional (CF, art. 84, VIII), também dispõe - enquanto Chefe de Estado que é - da competência para promulgá-los mediante decreto. (DJ, 10.08.2000).

Com efeito, preceitua a Constituição Brasileira em seu art. 49, I: “É da competência exclusiva do Congresso Nacional: I - resolver definitivamente sobre tratados, acordos ou atos internacionais que acarretem encargos ou compromissos gravosos ao patrimônio nacional.”

Por sua vez, estabelece o art. 84, VIII: “Compete privativamente ao Presidente da República: VIII - celebrar tratados, convenções e atos internacionais, sujeitos a referendo do Congresso Nacional."

Infere-se, portanto, dos artigos citados, estar a vinculação do Estado Nacional Brasileiro a tratados, acordos ou atos internacionais, condicionada ao exercício de competência de dois Poderes: o Executivo e o Legislativo. Ao Presidente da República cabe a prerrogativa de deflagrar o processo legislativo, remetendo ao Parlamento mensagem que encaminha: 1- texto de tratado celebrado pelo Chefe do Poder Executivo em nome do país; 2 - texto de tratado multilateral que, mesmo não tendo contado com a participação do país no ato inicial de celebração mereceria apreciação congressual para eventual adesão; e 3- texto de tratado oriundo de organização internacional. ${ }^{11}$

Uma vez ratificado pelo Congresso Nacional, que deve manifestar-se pelo voto da maioria relativa dos membros de cada Casa - art. 47 da Lei Maior - é promovido o retorno do ato internacional à Presidência da República, a fim de que o Chefe de Estado promova sua internalização na positividade jurídica.

\footnotetext{
${ }^{11}$ Tal posicionamento vem contemplando mudanças sob a perspectiva de equiparação dos tratados de direitos humanos à Lei Fundamental. Isso ficou evidente no julgamento da Ação Direta de Inconstitucionalidade n ${ }^{\circ} 1480-3 / D F$, que teve por objeto a Convenção $\mathrm{n}^{\circ} 158$ da OIT, segundo a qual "[...] os tratados ou convenções internacionais, uma vez regularmente incorporados ao direito interno, situam-se, no sistema jurídico brasileiro, nos mesmos planos de validade, de eficácia e de autoridade em que se posicionam as leis ordinárias, havendo, em conseqüência, entre estas e os atos de direito internacional público, mera relação de paridade normativa."
} 
Concernente à paridade normativa dos atos internacionais, o Supremo Tribunal Federal do Brasil tem mantido o entendimento de que os tratados internacionais, uma vez recepcionados, têm o status de lei ordinária. ${ }^{12}$

Suscitado conflito entre uma e outra, este se resolve pelo tradicional mecanismo da lei posterior revogar a anterior quando dela divergir. Todavia, há que se ter presente que a lei posterior não revoga o tratado internacional anterior, mas, simplesmente, afasta-o enquanto em vigor as normas com ele incompatíveis. Assim, revogada a lei que afastou a sua aplicação, voltará o tratado a ter eficácia. Prevalece, outrossim, o critério da especialidade em face da lei geral. Esse sistema de compatibilização se traduz pela corrente doutrinária que defende um direito internacional cujos subsistemas têm autonomia relativa, mas com uma base teórica mínima transversal, comum a todos os subsistemas jurídicos. Ou seja, há uma

${ }^{12}$ Encontra-se, atualmente, pendente de julgamento no Supremo Tribunal Federal o Habeas Corpus $n^{\circ} 87.585-8$-TO, no qual se discutiu a constitucionalidade da prisão do depositário infiel, considerando a ressalva do art. $5^{\circ}$, LXVII da Constituição Federal, em face do que dispõem a Convenção sobre Direitos Humanos, o Pacto de São José da Costa Rica (art. $7^{\circ}, \$ 7^{\circ}$ ) e o Pacto Internacional sobre Direitos Civis e Políticos da ONU (art. 11), ambos ratificados pelo Brasil. Trata-se de um conflito aparente de normas constitucionais nacionais originárias e supervenientes. Em voto prolatado, o Ministro Celso de Mello, numa mudança de posicionamento, assim se coloca: "Após longa reflexão sobre o tema em causa, Senhora Presidente - notadamente a partir da decisão plenária desta Corte na ADI 1.480 - MC/DF, Rel. Ministro Celso de Mello (RTJ 179/493-496) -, julguei necessário reavaliar certas formulações e premissas teóricas que me conduziram, então, naquela oportunidade, a conferir, aos tratados internacionais em geral (qualquer que fosse a matéria neles veiculada), posição juridicamente equivalente à das leis ordinárias.

"As razões invocadas neste julgamento, no entanto, Senhora Presidente, convencem-me da necessidade de se distinguir, para efeito de definição de sua posição hierárquica em face do ordenamento positivo interno, entre convenções internacionais sobre direitos humanos (revestidas de 'supralegalidade', como sustenta o eminente Ministro Gilmar Mendes ou impregnadas de natureza constitucional, como me inclino a reconhecer), e tratados internacionais sobre as demais matérias (compreendidos estes numa estrita perspectiva de paridade normativa com as leis ordinárias)".

Isso significa, portanto, examinada a matéria sob a perspectiva da 'supralegalidade', tal como preconiza o Ministro Gilmar Mendes, que, "cuidando-se de tratados internacionais sobre direitos humanos, este hão de ser considerados como estatutos situados em posição intermediária que permita qualificá-los como diplomas impregnados de estatura superior à das leis internas em geral, não obstante subordinados à autoridade da Constituição da República." 
fertilização cruzada em razão da influência do direito comunitário sobre o direito nacional. ${ }^{13}$

\subsection{A constituição da república oriental do Uruguai}

A Constituição da República Oriental do Uruguai, de 1967, sofreu várias reformas autorizadas por plebiscitos, nos anos de 1989 e 1996. Presentemente, o Estado Nacional do Uruguai rege-se por um texto constitucional, cujas últimas modificações entraram em vigor em janeiro de 1997.

Dispõe seu artigo $6^{\circ}$ :

"Artículo 60 - En los tratados internacionales que celebre la República propondrá la cláusula de que todas las diferencias que surjan entre las partes contratantes, serán decididas por el arbitraje u otros medios pacíficos."

La República procurará la integración social y económica de los Estados Latinoamericanos, especialmente en lo que se refiere a la defensa común de sus productos y materias primas. Asimismo, propenderá a la efectiva complementación de sus servicios públicos. (URUGUAI. Constituição 1967, Art. $6^{\circ}$.)

Tal qual a Constituição Brasileira de 1988, trata-se de norma de conteúdo programático, não podendo ser apontada como acolhedora do direito integracionista. Da leitura da última alínea exsurge visível contradição com os objetivos do Tratado de Assunção que visa, para além de uma mera zona livre de comércio entre os partícipes do Mercado Comum do Sul, o estabelecimento de uma tarifa externa comum, que propicie a inserção dos atores nacionais no livre comércio em escala mundial, por meio da abertura dos mercados (VENTURA, 2003, p. 218).

\footnotetext{
${ }^{13} \mathrm{O}$ fenômeno da fertilização cruzada encontra-se presente quando, por exemplo, altera-se o ordenamento jurídico nacional para fornecer tratamento especial ao direito internacional, Para aprofundar o conceito de fertilização cruzada confira-se, Mireille Delmas-Marty (2006).
} 
Diverge a doutrina sobre o alcance do dispositivo retro. Há quem vislumbre não autorizar o comando delegação ou transferência de competências nacionais a órgãos supranacionais. ${ }^{14}$ Outros entendem que ele poderia fundamentar compromissos no âmbito comunitário, se eles não violarem disposições constitucionais. Afirmam com supedâneo no art. $6^{\circ}$, que qualquer ato que obstaculize a integração seria inconstitucional e que a regra "[...] facilita a justificação jurídica da fase final do processo de integração para o governo uruguaio, inclusive eventual evolução para a supranacionalidade." 15

Certo é que, a despeito dos esforços doutrinários otimistas em favor do processo integracionista, o ordenamento constitucional uruguaio necessita de mudanças. ${ }^{16}$

${ }^{14}$ Neste sentido, Deisy Ventura, Eduardo Gallicchio e Hector Schiavone. En torno al TAs, Revista Uruguayaza de Derecho Constitucional y Político, n. 44, 2003, p.101 et seq. Para Roberto Ruiz Diaz Labrano (1998, p. 517), “[...] esta disposición se muestra limita para resolver la cuestión vinculada a la posibilidad de integrar órganos supranacionales o supraestatales, y ello es más lamentable por cuanto la reciente reforma parcial de la Constitución del Uruguay no incluyó este tema como punto a ser modificado."

${ }^{15}$ Heber Vignali (1994, p. 396-397), Deisy Ventura (2003, p. 219). Consultar, ainda, Carlos Delpiazzo, (1993, p. 611, 1999).

Em defesa desta posição, leia-se, Alejandro Perotti (2004, p. 516-517): "La hermenéutica de ambos párrafos del art. $6^{\circ}$ permite aseverar que en el contexto de un tratado de integración, resulta constitucionalmente ajustado al derecho uruguayo que se instituya un Tribunal de Justicia de carácter supranacional, encargado de asegurar la vigencia del derecho derivado del tratado y de su aplicación e interpretación de manera uniforme en todo el territorio comunitario. [...] en forma global, el art. $6^{\circ}$ de la constitución uruguaya habilita al Estado a ratificar tratados de integración con instituciones supranacionales, sean ésas de naturaleza legislativa, ejecutiva, administrativa o judicial, no siendo ello incompatible con el texto de la Carta, sino, en cierto sentido, exigida por ella a través de las finalidades para las cuales se ha autorizado la integración de Estado."

${ }^{16}$ Em 28 de outubro de 1993, foi proposto um projeto de reforma do artigo 6 ${ }^{\circ}$, pelo vice Presidente da Nação e Presidente do Senado, Dr. Gonzalo Aguirre Ramirez, que acrescia três alíneas do seguinte teor:

"\$ 3 . Os tratados que consagrem a citada integração, aprovados de acordo com o artigo 85,7 , fazem parte do direito nacional e fazem nascer, diretamente, direitos e obrigações para os habitantes da República, quando suas disposições forem diretamente aplicadas.

$\S \quad 4^{\circ}$. As resoluções dos órgãos criados por ditos tratados também se aplicarão aos habitantes da República quando forem obrigatórias para todas as pessoas, em virtude de seu conteúdo. 
Por fim, cumpre perscrutar acerca dos demais regramentos constitucionais que poderiam afetar o Mercosul. A Lei Maior Uruguaia prevê a transposição obrigatória das normas internacionais para a ordem interna, nos moldes do sistema dualista. O artigo 168, 20, confere ao Presidente da República competência para celebrar tratados, exigindo a aprovação parlamentar para a posterior ratificação.

De igual modo, o artigo 85, 7, atribui ao Poder Legislativo, poderes para:

[...] declarar a guerra e aprovar ou recusar, por maioria absoluta de votos do total de membros de cada Câmara (Senado e Câmara dos Deputados), os tratados de paz, aliança, comércio e as convenções ou contratos de qualquer natureza que o Poder Executivo conclua com as potências estrangeiras (CONSTITUIÇÃO DO URUGUAI, promulgada em 1967 e reformada em 1989, 1997 e 2004).

Decorre daí, que todas as regras exógenas devam ser submetidas à aprovação legislativa, incluindo as emanadas dos órgãos decisórios do Mercosul, pelo que, a aplicação direta do direito derivado do bloco afigura-se inaceitável para o Uruguai. ${ }^{17}$

Referente à hierarquia dos tratados internacionais, não se vislumbra na ratio constitucional nenhum dispositivo, podendo-se apenas depreender dos artigos

$\S \quad 5^{\circ}$. Não serão aplicáveis as leis incompatíveis com os referidos tratados e com as resoluções de ditos órgãos."

Tratava-se de disposição que estabelecia um novo regime jurídico aos tratados de integração latino americanos, declarando-os parte integrante dos ordenamentos positivos dos Estados-Partes. Conferia, outrossim, efeito direto às determinações comunitárias, ao instituir direitos e obrigações, não apenas ao Estado, mas às pessoas físicas e jurídicas, as quais poderiam se socorrer ante os tribunais nacionais em caso de descumprimento.

No parágrafo quarto regulava o direito derivado, conferindo-lhes idêntica equivalência à dos instrumentos fundacionais, no que respeita a sua vigência e eficácia imediata.

Lamentavelmente, o projeto foi rechaçado pelo Plenário da Câmara de Senadores, apesar de a Comissão Especial de Reforma da Constituição ter recomendado, em 16 de março de 1994, a aprovação do documento.

Para o texto integral da proposta de emenda consultar: Senado, Comisión Especial de Reforma de la Constitución de la República. Distribuído 2510, Carpeta n 1300, 1993, p. 6.

${ }^{17}$ Nesse sentido, orienta Maria Jose Vignone: "[...] a efectos de hacer viable la aplicación imediata de las decisiones, resoluciones y directivas de los órganos MERCOSUR “impõe-se a alteração da Constituição Oriental. (PEROTTI, 2004, p. 521). 
256 e 257 a supremacia da Constituição (DROMI SAN MARTINO, 2002, p. 92). ${ }^{18}$ Igualmente, os tratados internacionais dos quais é o Estado signatário, submetem-se à aprovação legislativa, consoante dispõe o inciso $7^{\circ}$ do art. 85, devendo, posteriormente, serem ratificados pelo Poder Executivo (art. 168, inciso 20) para adquirirem plena eficácia no território do Estado e incorporarem-se ao ordenamento jurídico interno.

Merece ser frisada a ausência do caráter político da integração, como objetivo a ser alcançado pelo Estado uruguaio, diferentemente da Constituição brasileira, que expressamente prevê esse aspecto em seu art. $4^{\circ}$, parágrafo único. Talvez este seja um entrave para, por exemplo, a delegação de competências ao Parlamento do ator regional Mercosul, recentemente instituído. Ademais, a ausência de uma integração política pode se constituir em um empecilho para delegação de competências a outros órgãos decisórios do bloco, caso seja implementado o instituto da supranacionalidade no bloco regional.

Assim, a supranacionalidade a traduzir-se na delegação de competências ao bloco regional, por força do art. $4^{\circ}$ da Constituição Uruguaia, resta vedada. Leia-se a definição do conceito de soberania para a ordem normativa do país: "La soberania en toda su plenitud existe radicalmente en la Nación, a la que compete el Derecho exclusivo de establecer sus leyes [...]".

Percebe-se, portanto, que Lei Maior Oriental refere-se à soberania no âmbito estatal, não a considerando sob a ótica internacional. Inclusive, não restam claro quais sejam seus limites ou, até que ponto o Estado Nacional concederia competências a entes supranacionais. Idêntico é o entendimento da jurista argentina Laura Dromi San Martino:

Sin embargo, y en cuanto la Constitución no se pronuncia sobre una regulación supranacional, puede entenderse que la integración que promueve es solo de naturaleza

\footnotetext{
${ }^{18}$ Sobre a matéria escreve, Roberto Labrano (1998, p. 517-518) "La Constitución uruguaya al igual que la del Brasil, no posee disposición expresa que resuelva el problema de la jerarquía de los tratados y las leyes comunes, y la interpretación que pueda surgir de la lectura de los artículos 256 y 239, sólo determinan la primacía constitucional."
} 
intergubernamental, dejando un vacío en cuanto a la posibilidad de hacerlo en el marco de organizaciones supranacionales. Así los órganos estatales carecen de competencia para transferir atribuciones a organismos de integración (DROMI SAN MARTINO, 2002, p. 92).

Dessa forma, a ausência de dispositivos constitucionais que autorizem a delegação de competências e facilitem a fertilização cruzada dificulta a participação do Uruguai em processos de integração regional, em especial no Mercosul, na medida em que sua positividade jurídica não permite o avanço do bloco regional em direção à autonomia e à independência política nas decisões, o que, certamente, proporcionaria maior celeridade à integração. ${ }^{19}$

Por fim, deve-se ressaltar a diferença normativa constitucional da cláusula integracionista uruguaia e brasileira, vez que esta última inclui a integração latino-americana em seu aspecto político, autorizando a delegação de competências a organismos supranacionais, diferentemente da primeira.

\subsection{A constituição da república do Paraguai}

A Constituição Nacional da República do Paraguai foi reformada em julho de 1992. Por ser uma Carta posterior à assinatura do Tratado de Assunção, sofreu os reflexos do processo de integração do Mercosul, prevendo em seu texto a possibilidade de delegação de competências. Desse modo, a Constituição integra o Paraguai ao grupo de Estados Membros do Mercosul o que facilita, sobremaneira, a fertilização cruzada.

Preliminarmente, impõe ressaltar que, ao contrário das Constituições uruguaia e brasileira, a Lei Fundamental paraguaia prevê a supremacia hierárquica dos tratados internacionais sobre as demais leis, consoante se denota da leitura dos

\footnotetext{
${ }^{19}$ Por sua vez, a Suprema Corte de Justiça relega os tratados internacionais ao status de lei ordinária, à semelhança do Supremo Tribunal Federal brasileiro. Vide: LJU, caso $\mathrm{n}^{\circ}$ 11.631, t. 102, 1991.
} 
artigos 137 e 141. A competência para sua conclusão compete ao Poder Executivo, conforme dispõe o artigo 238 , inc. $7^{\circ}$, correspondendo que se efetue a aprovação por lei do Congresso - art. 141. Tais assertivas conferem uma segurança jurídica maior no respeito aos tratados de integração firmados pelo Estado Nacional do Paraguai, sendo que, para denunciá-los é necessário passar por um procedimento rígido, previsto no art. 142 (REIS, 2006, p. 72). ${ }^{20}$

Por outro lado, a Lex Magna estabelece uma diferença no trâmite de aprovação legislativa do tratado internacional em geral e do tratado de integração. Enquanto o primeiro é aprovado por maioria simples, o tratado de integração deve, necessariamente, ser aprovado por maioria absoluta das duas Casas legislativas. Observa-se uma clara distinção estabelecida pelo constituinte com relação ao tema, denotando a importância e sérias consequências que um tratado de integração possui (REIS, 2006, p. 72-73).

Merece destaque, porém, a cláusula integracionista inserta no texto:

Art. 145. La República del Paraguay, en condiciones de igualdad con otros Estados, admite un orden jurídico supranacional que garantice la vigencia de los derechos humanos, de la paz, de la justicia, de la cooperación y del desarrollo, en lo político, económico, social y cultural. Dichas decisiones solo podrán adoptarse por mayoría absoluta de cada Cámara del Congreso.

O dispositivo reconhece um ordenamento jurídico supranacional, ou seja, uma base mínima transversal, que garanta a vigência de determinados valores constitucionais, ainda que sua admissão esteja condicionada à aprovação da maioria absoluta de ambas as Câmaras do Parlamento Paraguaio. Nesse diapasão, mes-

\footnotetext{
${ }^{20}$ Sobre o tema, escreve Roberto Labrano (1998, p. 504): “Al igual que em su anterior Constitución de 1987, la actual ha contemplado la prevalencia o primacía de los Tratados Internacionales sobre las leyes comunes, ubicándolos por debajo de la Constitución; en cuanto a lo tocante a las relaciones internacionales y la jerarquía de los Tratados Internacionales, en el Capítulo II, artículo 141 estabelece que los tratados internacionales válidamente celebrados, aprobados por ley del Congreso y cuyos instrumentos de ratificación fueran canjeados o depositados, forman parte del ordenamiento legal interno, además dispone que la jerarquía interna de la misma es posterior a la Constitución Nacional."
} 
mo que o Direito da Integração no ator Regional Mercosul não tenha tal caráter, a norma nacional possibilita a evolução da fertilização cruzada, por dar suporte jurídico a eventuais mudanças institucionais no bloco regional, fornecendo ferramentas legais para a consolidação da integração do Cone Sul (MIZUTANI, 2006, p. 83).

A diferença deste texto para as Constituições brasileira e uruguaia é evidente, já que a autorização constitucional aqui é expressa, não sendo necessário realizar nenhuma interpretação aberta ou dispor considerações acerca do conceito de soberania em constante mutação. Com efeito, em muito se assemelha à Constituição argentina que, dois anos depois, realizou sua reforma constitucional e inseriu cláusula constitucional favorável à integração. (REIS, 2006, p. 73).

$\mathrm{O}$ art. 145 não taxa quais seriam as matérias possíveis de delegação de competências a um órgão supranacional, no entanto, conforme ressalta Perotti, pode-se depreender que são todas aquelas descritas no próprio caput do artigo, quais sejam, direitos humanos, paz, justiça, além das necessárias para o bom desenvolvimento e cooperação da integração, especialmente, nos campos político, econômico, social e cultural (PEROTTI, 2004, p. 369). Portanto, a Constituição, ao admitir uma ordem jurídica supranacional, autoriza a instalação de um direito regional comunitário com todas as suas características: efeito imediato, princípio da primazia e aplicabilidade direta.

Outro não é o entendimento, ao proceder-se interpretação sistemática do caput do artigo 145 com os seus dois parágrafos com o próprio preâmbulo da Carta paraguaia que proclama:"El pueblo paraguayo, [...]ratificando la soberanía e independencia nacionales, e integrado a la comunidad internacional, sanciona y promulga esta Constitución.”

Assim, uma vez aprovado o tratado de integração na conformidade constitucional, figura-se dispensável a incorporação ao ordenamento jurídico nacional, mediante referendo legislativo do direito nacional derivado, quando este é decorrente dos tratados fundacionais, o que facilita a fertilização cruzada (PEROTTI,

\footnotetext{
${ }^{23}$ Dispõem os referidos artigos:

“Art. 137. De la Supremacía de la Constitución

La ley suprema de la República es la Constitución Esta, los tratados, convenios y acuerdos
} 
2004, p. 372-373). De fato, os artigos 137 e 141 da Constituição asseguram que as normativas mercosulinas desfrutarão, tal qual o direito orginário, frente à legislação interna infraconstitucional, superioridade hierárquica. ${ }^{21}$

Em conclusão, a Constituição da República do Paraguai de 1992 estabeleceu uma série de enunciações que demonstram a vontade política dos constituintes em apoiar os processos de integração e fundar a primazia do direito comunitário sobre uma base distinta do direito internacional geral.

\subsection{A constituição argentina}

A Constituição Nacional da República da Argentina data de 1853, tendo sido reformada em 1860, 1866, 1898, 1957 e, por último, em 1994.

A Constituição vigente, cuja alteração foi promulgada em 28 de agosto de 1994, possui um texto contemporâneo e fortemente influenciado pelos processos integracionistas em vigor, prevendo, inclusive, a supranacionalidade, nos mesmos moldes da Lei Fundamental Paraguaia. Tal precisão constitucional é elemento que propicia a fertilização cruzada.

Primeiramente, cabe analisar o tratamento conferido pela Carta portenha aos tratados internacionais celebrados pelo Estado Nacional da República Argentina, à luz do disposto nos artigos 27, 30, 31 e 75, incisos 22 e $24 .^{22}$

internacionales aprobados y ratificados, las leyes dictadas por el Congreso y otras disposiciones jurídicas de inferior jerarquía, sancionadas en su consecuencia, integran el derecho positivo nacional el orden de prelación enunciado."

"Art.141. De los Tratados Internacionales

Los tratados internacionales válidamente celebrados, aprobados por ley del Congreso, cuyos instrumentos de ratificación fueran canjeados o depositados, forman parte del ordenamiento legal interno con la jerarquía que determina el artículo 137."

${ }^{22}$ Leiam-se:

"Art.27. El Gobierno federal está obligado a afianzar sus relaciones de paz y comercio con las potencias extranjeras por medio de tratados que estén en conformidad con los principios de derecho público establecidos en esta Constitución." 
Prevê o artigo 27 da Lei Maior que os tratados internacionais celebrados pelo governo federal estejam conformes com os princípios de direito público estabelecidos na Carta Magna. A fertilização cruzada encontra respaldo, na necessidade da compatibilização que vai ao encontro, ainda que implicitamente, de um controle de constitucionalidade prévio dos instrumentos internacionais, visando impedir qualquer redução de garantias dispostas na Primeira e Segunda parte do texto constitucional nacional.

Quanto ao artigo 30, sua importância para o tema centra-se na preponderância atribuída pela Constituição aos tratados internacionais, em especial, os de direitos humanos. Estatui a norma em epígrafe que a Carta somente poderá ser reformada após um longo procedimento, que inclui: (i) a necessidade de reforma declarada pelo Congresso por meio do voto de dois terços de seus membros; e (ii) a convocação de uma Convenção ou Assembleia Constituinte designada estritamente para levar a cabo tal feito.

Decorre da leitura desse artigo que a concessão de hierarquia constitucional a determinados tratados internacionais e, por conseguinte, a possibilidade de

\footnotetext{
"Art. 30. La Constitución puede reformarse ene. Todo o en cualquiera de sus partes. La necesidad de reforma debe ser declarada por el Congreso con el voto de dos terceras partes, al menos, de sus miembros; pero no se efectuará sino por una Convención convocada al efecto."

"Art. 75. Corresponde al Congresso:

"22. Aprobar o desechar tratados concluidos con las demás naciones y con las organizaciones internacionales y los concordatos con la Santa Sede. Los tratados y concordatos tienen jerarquía superior a las leyes. (omissis)"

"24. Aprobar tratados de integración que deleguen competencias y jurisdicción a organizaciones supraestatales en condiciones de reciprocidad e igualdad, y que respeten el orden democrático y los derechos humanos. Las normas dictadas en su consecuencia tienen jerarquía superior a las leyes.

"La aprobación de estos tratados con Estados de Latinoamérica requerirá la mayoría absoluta de la totalidad de los miembros de cada Cámara. En el caso de tratados con otros Estados, el Congreso de Nación, con la mayoría absoluta de los miembros presentes de cada Cámara, declarará la conveniencia de la aprobación del tratado y sólo podrá ser aprobado con el voto de la mayoría absoluta de la totalidad de los miembros de cada Cámara depuse de ciento veinte días del acto declarativo.

"La denuncia de los tratados referidos a este inciso, exigirá la previa aprobación de la mayoría absoluta de la totalidad de los miembros de cada Cámara."
} 
alteração parcial do texto constitucional por tratados, em especial de direitos humanos, lesa o procedimento estabelecido no mesmo artigo. ${ }^{23}$

No tocante ao disposto no artigo 31, ele aponta a "hierarquia federativa" que os tratados internacionais possuem na positividade, estabelecendo que a Constituição, as leis editadas pelo Congresso e os tratados são a Lei Suprema da Nação.

Dele se depreende que a qualificação de lei suprema é apenas para diferenciar a ordem normativa federal da ordem provincial, diante da grande autonomia que as províncias argentinas possuem em seu sistema federativo. Por outro lado, destaca-se a obrigatoriedade de observância que a Lei Suprema possui sobre todos os ordenamentos jurídicos provinciais (REIS, 2006, p. 70).

Adentrando ao cerne da questão, chega-se ao artigo 75 da Lei Maior que disserta acerca das competências do Congresso. Seu inciso 22 atribui ao Poder Legislativo competência para aprovar ou rejeitar tratados firmados com os demais Estados Nacionais ou organizações internacionais, outorgando-lhes hierarquia superior às leis. O parágrafo primeiro confere hierarquia constitucional aos tratados de direitos humanos e o segundo constitucionaliza os demais tratados de direitos humanos, quando ultrapassado o procedimento previsto.

Outrossim, cabe ressaltar o caráter de supralegalidade que o inciso 22 proporciona aos tratados internacionais em geral, confirmando a presença dos mesmos na Lei Suprema da Nação, consoante o art. 31.

Sem dúvida, o dispositivo constitucional argentino de maior importância para o ator regional Mercosul é o previsto pelo art. 75, inc. 24, da Constituição Nacional, porque reconhece e autoriza o Estado a delegar competências e jurisdição a organismos supranacionais.

${ }^{23}$ A propósito assinala Alejandro Perotti (1998, p. 775): “[...] el art. 30 constitucional, así definido, constituye un fundamento complementario que apuntala la jerarquía extraordinária que benefecia a la constitución." Habilitación constitucional para la integración comunitaria. 
Por derradeiro, convém lembrar que os tratados internacionais em geral são celebrados pelo Presidente, conforme o art. 99, inciso 11, e, posteriormente, ratificados pelo Congresso, consoante o art. 75, inciso 22. Quanto ao procedimento, é importante distinguir os tratados regionais de integração que deverão ser aprovadas por maioria absoluta da totalidade dos membros de cada Casa Legislativa, quando envolverem Estados latino-americanos, daqueles outros pactuados com os demais Estados Nacionais, cujo procedimento será mais rigoroso. Veja-se que essa diferenciação resulta em uma fertilização de nível regional mais presente, já que as de nível mundial encontram maior barreira no processo de internalização das normas internacionais. Desse modo, a Carta Magna Argentina parece admitir a delegação de competências e jurisdição a organismos supraestatais, ${ }^{24}$ o que não impediria, por exemplo, a instalação de um Parlamento do Mercosul nos moldes supranacionais.

Conclui-se, pois, que a Constituição Argentina possui uma visão contemporânea de soberania compartilhada no tocante aos processos integracionistas, propiciando, caso as instâncias governamentais e diplomáticas assim decidam, um avanço do Mercosul nas matérias e órgãos que lhe convier (DROMI SAN MARTINO, 2002, p. 90).

\subsection{A constituição da república bolivariana da Venezuela}

A despeito de a Venezuela encontrar-se em procedimento de adesão ao Mercado Comum do Sul, tendo como marco inicial a XXIX Conferência do Mercosul, sediada na cidade de Montevidéu, em dezembro de 2005, ocasião na qual lhe foi outorgado o status de Estado Nacional em processo de adesão por meio do Acordo-Quadro para a Adesão da República Bolivariana da Venezuela ao ator

\footnotetext{
${ }^{24}$ Laura Dromi San Martino (2002, p. 86) adverte que "La norma constitucional posibilita que al aprobarse tratados de integración se deleguen competências y jurisdicción, y en la hermenéutica de la Constitución argentina debe considerarse que el destinatario de esa delegación sólo puede ser un organismo supraestatal, concepto que podría identificarse con el carácter supranacional, por lo tanto nunca podría hacerse en favor de otro Estado extranjero".
} 
regional Mercosul, ${ }^{25}$ importa analisar sua sistemática constitucional para aferir o grau de juridicidade integracionista de sua ordem normativa nacional, ou seja, seu grau de abertura para a fertilização cruzada.

A Constituição da República Bolivariana da Venezuela, promulgada em 17 de novembro de 1999, possui dois dispositivos constitucionais a serem destacados: $v g$ : o artigo $73, \S 2^{\circ}$; e o artigo 153 , que estatuem, respectivamente:

Articulo 73 [...] Los tratados, convenios o acuerdos internacionales que pudieren comprometer la soberanía nacional o transferir competencias a órganos supranacionales, podrán ser sometidos a referendo por iniciativa del Presidente o Presidenta de la República en Consejo de Ministros; por el voto de las dos terceras partes los y las integrantes de la Asamblea o por el quince por ciento de los electores y electoras inscritos en el registro civil y electoral.

Artículo 153. La República promoverá y favorecerá la integración latinoamericana y caribeña, en aras de avanzar hacia la creación de una comunidad de naciones, defendiendo los intereses económicos, sociales, culturales, políticos y ambientales de la región. La República podré suscribir tratados internacionales que conjuguen y coordinen esfuerzos para promover el desarrollo común de nuestras naciones, y que aseguren el bienestar de los pueblos y la seguridad colectiva de sus habitantes. Para estos fines, la república podrá atribuir a organizaciones supranacionales, mediante tratados, el ejercicio de las competencias necesarias para llevar a cabo estos procesos de integración. Dentro de las políticas de integración y unión con Latinoamérica y el Caribe, la República privilegiará relaciones con Ibero América procurando sea una política común de toda nuestra América Latina. Las normas que se adopten en el marco de los acuerdos de integración serán consideradas parte integrante del ordenamiento legal vigente y de aplicación directa y preferente a la legislación interna.

O artigo 73 reconhece a existência de órgãos supranacionais e regulamenta a aprovação, por quórum especial, dos tratados internacionais que versam sobre essa matéria. A norma nacional consubstancia hipótese de transformação do direi-

${ }^{25}$ Sobre o processo de adesão da Venezuela ao Mercosul consultar: ROCHA, DOMINGUES, RIBEIRO (2008). 
to da integração em direito supranacional, em seu aspecto institucional, em caso de aprovação pelo Conselho de Ministros pelo voto de dois terços dos integrantes da Assembleia ou por quinze por cento dos eleitores.

Entretanto, é o artigo 153 da Constituição que encerra a ideia integracionista quando declara a vontade política do Estado em aproximar-se da América Latina e Caribe, perspectivando o estabelecimento de uma comunidade regional de nações e habilitando o Estado Nacional a assinar tratados internacionais relativos a órgãos supranacionais, conformando assim, uma abertura para a fertilização cruzada.

\section{Conclusão}

Dentre as Constituições examinadas, por certo, a venezuelana é a que apresenta redação mais consentânea com o espírito comunitário, ou seja, é a que melhor propicia a formação de uma base mínima transversal. Nesse diapasão, a abertura constitucional das Leis Fundamentais dos Estados Argentino, Paraguaio e Venezuelano facilitará o desenvolvimento da proposta mercosulina e auxiliarão a superação de um direito transitoriamente integracionista.

Muito embora as Constituições brasileira e uruguaia não contenham normas de alcance semelhante seus artigos $4^{\circ}$, parágrafo único e $6^{\circ}$, respectivamente, em tese, encerrariam possibilidades hermenêuticas de interpretação jurisprudencial favorável à integração, refutadas, contudo, pelo Supremo Tribunal Federal.

Some-se a isso a necessidade de se compatibilizar os compromissos formais assumidos pelo Brasil perante a comunidade de países com os parâmetros sistêmicos do arcabouço jurídico estatal. Seu equacionamento deveria ser objeto de uma reforma constitucional com vistas a institucionalizar um sistema dualista efetivamente integrador.

Nesse contexto, imperativo que se reabram as discussões levantadas durante o processo de revisão constitucional realizado 5 anos após a promulgação 
da Carta Política Nacional, no sentido de conciliar o atributo da soberania com a obrigatoriedade do cumprimento de regras livremente aceitas na ordem externa, mormente, no âmbito do Mercado Comum do Sul.

Naquela época, tomando como paradigma a Constituição Portuguesa que assimilou a aplicabilidade direta das normas provenientes dos organismos internacionais, pretendeu-se acrescentar ao art. $4^{\circ}$, parágrafo inédito, com o seguinte texto: "As normas gerais e os princípios de Direito Internacional Público são parte integrante do direito brasileiro."

Diante das resistências exegéticas do Supremo Tribunal Federal que, expressamente, manifestou-se contrário ao reconhecimento da autonomia conceitual do efeito direto - aptidão da norma internacional repercutir desde logo em matéria de direitos e obrigações na esfera jurídica dos particulares - e da aplicabilidade imediata - vigência automática da norma internacional na ordem jurídica interna - dos Tratados e normas derivadas Mercosul, sob o entendimento de que tais diretrizes não se acham consagradas e nem positivadas no texto da Constituição da República, razão pela qual não poderiam ser invocadas para legitimar a incidência no plano doméstico de qualquer convenção internacional, ainda que se cuide de tratado de integração, enquanto não concluídos os diversos ciclos do processo de incorporação, ${ }^{26}$ a intervenção do Poder Constituinte derivado revela-se providencial.

Ademais, reconheceu a Excelsa Corte que, por se tratar de princípios que compõem o direito de integração, o efeito direto e a aplicabilidade imediata qualificar-se-iam como diretrizes essenciais à própria configuração institucional do espaço comunitário, porquanto tais postulados visam tornar as regras comunitárias imediatamente invocáveis em matéria de direitos e obrigações pelos particulares, além de aplicáveis, desde logo, sem qualquer intermediação formal, nas ordens normativas dos Estados Partes. Uma vez integrantes de um sistema normativo, orientarão a atuação do juiz nacional, que é juiz comunitário de direito comum.

\footnotetext{
${ }^{26}$ Carta Rogatória dos Coagulantes Argentinos.
} 
Outra sugestão de reforma de teor semelhante ao disposto na Carta Portuguesa e discutida no processo de revisão da Constituição Brasileira propugnava que: "As normas emanadas dos órgãos decisórios do Mercosul de que a República Federativa do Brasil seja parte vigoram na ordem interna, desde que expressamente estabelecido nos respectivos tratados constitutivos.”

Tal proposta chegou a obter o apoio da maioria dos membros do Congresso (168 votos a favor e 114 contrários), porém, não logrou aprovação porque o quorum mínimo exigido era o da maioria absolta, nos termos do art. $3^{\circ}$ dos ADCTs.

Lamentável a sua rejeição, sabido que a referência às organizações internacionais não é inédita no constitucionalismo pátrio. Na Carta de 1946, fruto do pós-guerra, quando se buscava a integração como condição para se evitar nova tragédia, os constituintes fizeram inserir no art. $4^{\circ}$ - tendo em vista a Organização das Nações Unidas e o respectivo Conselho de Segurança - referência expressa a ente de natureza supranacional. Dispunha a Lei pretérita:

O Brasil só recorrerá à guerra se não couber ou se malograr o recurso ao arbitramento ou aos meios pacíficos de solução de conflito, regulados por órgão internacional de segurança, de que participe; e em caso nenhum se empenhará em guerra de conquista, direta ou indiretamente, por si ou em aliança como outro Estado (CONSTITUIÇÃO BRASILEIRA DE 1946, Art. $4^{\circ}$.)

Também o texto constitucional de 1967, em redação mantida pela Emenda de 1969, previa no art. $7^{\circ}$ que: "Os conflitos internacionais deverão ser resolvidos por negociações diretas, arbitragem e outros meios pacíficos, com a cooperação dos organismos internacionais de que o Brasil participe".

Para além dessas alterações, dever-se-ia atribuir maior relevância aos pactos internacionais, conferindo-lhes status de supralegalidade, tal qual a Constituição Argentina - art. 75, 22, e estabelecer um quorum parlamentar privilegiado para a sua adesão. Igualmente ao Congresso Nacional, caberia a atribuição de não apenas resolver definitivamente sobre tratados, mas também de deliberar sobre a sua denúncia. Outro ponto fundamental seria o exame prévio da constitucionalidade pelo STF, a exemplo da Constituição de Espanha - art. 95 - e da França - art. 
54, como forma de decisão antecipatória de possível incompatibilidade com a Lei Maior, tendo a decisão efeito vinculante, a condicionar a aprovação pelo Parlamento de emenda constitucional exigível. Por fim, a submissão de certos Pactos à vontade coletiva, por meio da utilização de instrumentos da democracia direta - referendum e plebiscito - nos termos do preceituado no art. 49, XV da CF, valorizaria o Estado Democrático de Direito.

Efetivamente, a adoção de tais medidas prestigiaria não apenas os ideais contemporâneos de integração entre Nações irmãs; inspirariam, igualmente, o sonho de Bolívar que aclamou em lutas heróicas pela independência da Latina América: "Não sei como não se levantaram ainda todos estes povos e soldados ao concluírem que os seus males não vêm da guerra, mas de leis absurdas!” 27

\section{The incorporation of mercosur's norms and the member-states' constitutions. the challenge of overcoming legal framework}

\section{Abstract}

This article aims at analyzing the process of incorporating Mercosur's legal framework deriving from the bloc's decision-making institutions with a view to assessing the progress of the integration process in the juridical sphere. Accordingly, the Constitutions of each member-State will be separately considered in order to evaluate the importance attributed to Mercosur's Law in the countries' internal juridical framework.

Keywords: Mercosur. Integration Law. Mercosur's legal framework. Intergovernability. Constitution.

${ }^{27}$ Citação extraída da obra BOLIVAR, El hombre de América: presencia y camino de autoria HERRERA TORRES, Juvenal. Medellín: Convivencias, 2000. 


\section{Referências}

BAPTISTA, Luiz Olavo. As instituições do Mercosul: comparações e prospectiva. In: FREITAS, Deisy de (Coord.). O Mercosul em movimento. Porto Alegre: Livraria do Advogado, 1995.

BASTOS, Celso Ribeiro. Curso de direito constitucional. 16. ed. São Paulo: Saraiva, 1994.

BRASIL. Constituição (1946). Constituição da República Federativa do Brasil. Disponível em: <http://www.planalto.gov.br/ccivil_03/constituicao/ constitui\%C3\%A7ao46.htm>. Acesso em: 15 jan. 2011.

BRASIL. SUPREMO TRIBUNAL FEDERAL. Carta Rogatória nº 8.279-4.

DALLARI, Pedro. Constituição e relações exteriores. São Paulo: Saraiva, 1994.

DELMAS-MARTY, Mireille. Por um direito comum. Tradução Matria Ermantina de Almeida Padro Galvão. São Paulo: M. Fontes, 2004.

DELMAS-MARTY, Mireille. Les forces imaginantes du droit: le pluralisme ordonné, les forces imaginantes du droit. Paris: Seuil, 2006.

DELPIAZZO, Carlos. Armonización jurídica e incorporación de normas comunes al derecho interno en el Mercosur. Revista de Derecho Administrativo, Buenos Aires, n. 14, 1993.

DELPIAZZO, Carlos. El derecho de la integración del Mercosur. Montevideo: Universidad de Montevideo, 1999.

DROMI SAN MARTINO, Laura. Derecho constitucional de la integración. Buenos Aires: Ciudad Argentina, 2002.

FERREIRA FILHO, Manoel Gonçalves. Comentários à constituição brasileira de 1988. São Paulo: Saraiva, 1990. v. 1.

GOMES CANOTILHO, J.J. Direito Constitucional. Coimbra: Almedina, 1991.

LABRANO, Roberto Ruiz Diaz. Mercosur integracion y derecho. Buenos Aires: Intercontinental, 1998. 
MIZUTANI, Larissa Caetano. Direito da integração: a transitoriedade jurídica no Mercosul. 2006. Dissertação (Mestrado)-Programa de Iniciação Científica: Curso de Direito do Centro Universitário de Brasília, Brasília, 2006.

PEROTTI, Alejandro Daniel. Habilitación constitucional para la integración comunitária: estúdio sobre los estados del Mercosur. 2. ed. Montevideo: K. Adenauer Stiftung, 2004.

REIS, Rafael Nascimento. Mercosul: soberania e supranacionalidade. 2006. Trabalho de Conclusão de Curso (Graduação)-Curso de Bacharel em Direito, Centro Universitário de Brasília, Brasília, 2006.

ROCHA, Maria Elizabeth Guimarães Teixeira; DOMINGUES, Leyza Ferreira; RIBEIRO, Elisa de Sousa. A adesão da Venezuela ao MERCOSUL. O manifesto da expansão integracionista. Revista de Informação Legislativa do Senado, Brasília, n. 177, jan./mar. 2008.

TORRES, Juvenal Herrera. Bolivar, el hombre de América: presencia y Camin. Medellín: Convivencias, 2000.

URUGUAY. Constitución de la Republica (Constitución 1967 con las Modificaciones Plebiscitadas el 26 de Noviembre de 1989, el 26 de Noviembre de 1994 y el 8 de diciembre de 1996). Disponível em: http://www.parlamento.gub.uy/constituciones/ const997.htm. Acesso em jan. 2011.

VENTURA, Deisy. As assimetrias entre o Mercosul e a União Europeia. São Paulo: Manole, 2003.

VIGNALI, Heber. "Seccion III: las estructuras de las organizaciones económicas y otras". Revista Derecho Internacional Público, T.V., Montevidéu: Fundación Cultura Universitaria, 1994. p. 396-397. 


\section{Para publicar na revista Universitas}

Relações Internacionais, entre no endereço eletrônico www.publicacoesacademicas.uniceub.br. Observe as normas de publicação, facilitando e agilizando o trabalho de edição. 